\title{
Perceived Satisfaction and Perceived Usefulness of E- Learning: The Role of Interactive Learning and Social Influence
}

\author{
Ares Albirru Amsal ${ }^{1, *}$ Siska Lusia Putri ${ }^{2}$ Febri Rahadi ${ }^{2}$ Mellyna Eka Yan Fitri ${ }^{2}$ \\ ${ }^{1}$ Department of Management Faculty of Economics Universitas Andalas, Padang West Sumatra Indonesia \\ ${ }^{2}$ Department of Management Faculty of Economics and Business Universitas Dharma Andalas, Padang West Sumatra \\ Indonesia \\ *Corresponding author. Email: aresalbirruamsal@eb.unand.ac.id
}

\begin{abstract}
Understanding the factors that influence the satisfaction of e-learning is critical. Therefore, this study aims to investigate the relationship between interactive learning, social influence, and perceived usefulness on perceived satisfaction with e-learning. Seventy-three students taking online learning were surveyed using a questionnaire. The results of the structural equation modelling analysis show that interactive learning and perceived usefulness have a significant effect on e-learning perceived satisfaction. However, when social influence affects perceived usefulness significantly, the effect of interactive learning on perceived usefulness is insignificant. This research is useful for academics, teachers, lecturers, and university ICT to put the concern to student satisfaction factors in online learning.
\end{abstract}

Keywords: Interactive learning, Social influence, Perceived usefulness, E-learning, Perceived satisfaction

\section{INTRODUCTION}

E-learning is a form of the latest development of distance learning, where instructors and students can be at different places and times in the teaching and learning process [1]. E-learning uses information communication technology to convey information or teaching material without geographical barriers and time constraints. The learning paradigm of e-learning is a new approach and continually developing world of education [2]. This online learning approach expands the interaction between instructors and students, removing space and time boundaries through asynchronous and synchronous devices [3].

Bouhnik and Marcus [4] stated that e-learning has four benefits: freedom in determining the lessons to be studied, minimal dependence on lecturers, freedom to express opinions, thoughts, equate questions without obstacles, and the ease of obtaining learning material according to student interests. With the benefits that elearning offers and the development of the internet, elearning systems are now widely used in universities [5].
However, despite the many benefits that e-learning systems offer and the massive development of users in recent years, research shows that not all students use it until the end of courses [6]. It indicates that there is something that affects the use of the e-learning system. Other factors need to be explored so that improvements can be made to online learning. Previous research by Bouhnik and Marcus [4] revealed the factors causing dissatisfaction with e-learning, namely: lack of institutional support that encourages students to learn, the need for high self-discipline, there is no learning atmosphere in the system, distance learning systems reduce contact, discussion, between students and instructors, and a less efficient learning process. Other factors identified in previous studies are the clarity of design, interaction with instructors, and active discussion [7]. These factors can increase student satisfaction with e-learning.

Understanding student attitudes towards e-learning is an essential issue for the world of education today. Therefore, this study tries to explore other factors that influence student satisfaction. In this study, we choose Moodle as an e-learning platform. 


\subsection{Effective e-learning}

E-learning refers to any electronic device intended for learning, including sharing electronic content via computer networks, audio, broadcast, interactive tv, and others [2]. As learning activities have become more individualized, student-centered e-learning technology has become more personalized, user-centered, networked, and durable [8]. The character of e-learning fulfills students' needs in the digital era and has attracted educational and business institutions to develop it [3].

To improve e-learning users' experiences, Liaw and Huang [9] suggested four elements that need to be considered for building a learning environment: useful environmental characteristics, enhancing environmental satisfaction, practical learning activities, and positive learners' characteristics.

\subsection{Interactive learning}

An interactive learning environment involves communication and exploration of activities [10]. Communication activities include email, chat forums, online conferencing, and blogs, which are suitable for asynchronous and synchronous social communication. On the other hand, exploration activities include surfing the internet to find lecture content. Therefore, the elearning environment offers interaction types such as learning content interaction, student-to-student communication, and student-instructor communication.

In the e-learning system, students carry out social and interpersonal interactions via a computer or smartphone, not through face-to-face communication. In some aspects, e-learning offers excellent potential for social and interpersonal communication that faceto-face communication does not have. Communication such as asking, answering, discussing, debating, and negotiating can be done online between students and lecturers and among the e-learning system [11].

Asynchronous communication is communication using technology that is independent of instructors or other users. In asynchronous communication, students work with themselves and have control over their learning phase. Synchronous communication is carried out in real-time, where it takes the presence of instructors and other users simultaneously. Based on previous research, interactive learning positively affects user satisfaction [10], [12]. Moreover, interactive learning also affects the perceived usefulness of the e-learning system [13].

\subsection{Social Influence}

Thompson et al. explained that Social influence represents the environmental influence in shaping behavior [14]. In online learning, the social environment includes colleagues and instructors. If these individuals encourage the use of e-learning systems, students will be more interested in using it [15]. Social interaction is also included in environmental factors that are outside the student. The model developed by Liaw [13] explained that environmental factors affect perceived usefulness.

\subsection{Perceived usefulness}

In most cases, the usefulness of a system affects learning effectiveness [16]. Usability is a quality that reflects the ease of use in human and computer interactions [17]. The international standard ISO 9241 defines it as the ease of a product in meeting user objectives effectively, efficiently, and satisfactorily. Liaw [13] explained that perceived usefulness affects perceived satisfaction.

\subsection{Perceived satisfaction}

Perceived satisfaction is the user's acceptance of a system and the level of comfort in its use. It can also be interpreted as the pleasure that a person feels when he takes action and then gets the result [2]. The concept of satisfaction is the aggregate of a person's feelings on several factors that affect a particular situation. Doll and Torkzadeh [18] defined satisfaction as a condition of how users feel about a given system. The high level of user satisfaction will affect the level of willingness to use the system in the future.

\subsection{Research hypothesis}

Based on the literature review, the researcheroffers the following research hypothesis:

H1: Interactive learning will positively affect perceived satisfaction

$\mathrm{H} 2$ : Interactive learning will positively affect perceived usefulness

$\mathrm{H} 3$ : Social influence will positively affect perceived usefulness

H4: Perceived usefulness will positively affect perceived satisfaction

The research hypothesis is illustrated in the research framework in Figure 1. 


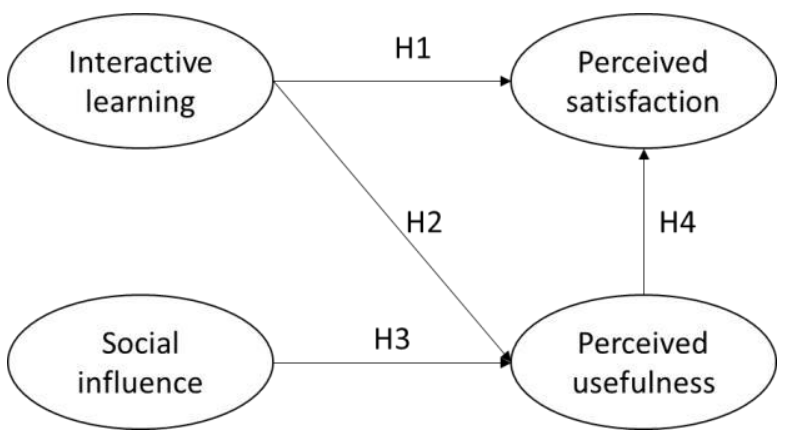

Figure 1 Research framework and hypothesises

\section{METHODS}

\subsection{Participant}

The research subjects were users of the Modular Object-Oriented Dynamic Learning Environment (Moodle). Moodle is a web-based platform explicitly created as a learning management system. It is an option to make teaching and learning activities more effective. So, all teaching and learning activities are carried out by accessing the website using a browser. This system has main features: distributing a subject matter, collecting assignments, quizzes, attendance, and monitoring learning activities' progress.

Questionnaires were distributed online to participants by collecting basic demographics data and questions regarding their e-learning experience. Of the 91 questionnaires collected, 18 were excluded because of invalid responses, leaving 73 valid answers.

\subsection{Measurements}

The questionnaire was adapted from research by Liaw [13], Liaw and Huang [10], and Prasad et al. [15]. The research questions were then adapted to suit the conditions of students in the city of Padang. The questionnaire consists of two parts: the demographic section and the questioning section related to research variables. Demographic information includes age, gender, average monthly expenditure, data access to the internet, electronic communication devices used, length of time spent surfing the internet in a day, length of time using computers (computer skills/literacy), and previous online learning experiences. Questions related to variables include "interactive learning," "social influence," "perceived usefulness," and "perceived satisfaction." Items related to these four variables are measured using a 5-Likert scale where the number 1 reflects strongly disagree, and number 5 reflects strongly agree. Questions are submitted in Indonesian after peer review of the translation results. Variables, number of questions, and reference sources are shown in Table 1.
Table 1. Variables, questions quantity, dan references

\begin{tabular}{|l|l|l|}
\hline Constructs & Q & Reference \\
\hline $\begin{array}{l}\text { Interactive Learning } \\
\text { (ILE) }\end{array}$ & 4 & $\begin{array}{l}\text { Liaw [13], Liaw } \\
\text { and Huang [10] }\end{array}$ \\
\cline { 1 - 2 } $\begin{array}{l}\text { Perceived Usefulness } \\
\text { (PU) }\end{array}$ & 3 & \\
\cline { 1 - 2 } $\begin{array}{l}\text { Perceived Satisfaction } \\
\text { (PS) }\end{array}$ & 3 & \\
\hline Social Influence (SI) & 3 & Prasad et al. [15] \\
\hline Total & 16 & \\
\hline
\end{tabular}

\section{RESULTS AND DISCUSSION}

\subsection{Demographics}

More than half of the participants (78\%) were female. The average age is 21.7 years, which indicates the average age of students in semester 7 or 8 . The majority of respondents' monthly expenses are Rp. $500,000-1,000,000(64 \%)$. Almost all of them use personal data to access the internet, and less than a fifth $(18 \%)$ of respondents use home WiFi.

Regarding the devices used, $96 \%$ of respondents use smartphones, followed by $34 \%$ of laptops. The time spent on the internet is relatively evenly distributed, between 1 to more than 6 hours per day (18\%-30\%), but only three respondents spent less than 1 hour. Fortyseven respondents (64\%) have never used online learning, and another quarter has ever used e-learning. 
Table 2. Demographics of participant

\begin{tabular}{|c|c|c|c|}
\hline Profiles & Item & Q & $\%$ \\
\hline \multirow{2}{*}{ Sex } & Male & 16 & $22 \%$ \\
\hline & Female & 57 & $78 \%$ \\
\hline Age & \multicolumn{3}{|c|}{ Average: 21,7 y.o } \\
\hline \multirow{6}{*}{$\begin{array}{l}\text { Average } \\
\text { expenditure per } \\
\text { month (IDR) }\end{array}$} & $\begin{array}{l}\text { Less than } \\
500.000\end{array}$ & 8 & $11 \%$ \\
\hline & $\begin{array}{l}500.000- \\
1.000 .000\end{array}$ & 47 & $64 \%$ \\
\hline & $\begin{array}{l}1.000 .000- \\
1.500 .000\end{array}$ & 13 & $18 \%$ \\
\hline & $\begin{array}{l}1.500 .000- \\
2.000 .000\end{array}$ & 1 & $1 \%$ \\
\hline & $\begin{array}{l}2.000 .000- \\
3.000 .000\end{array}$ & 0 & $0 \%$ \\
\hline & $\begin{array}{l}\text { More than } \\
3.000 .000\end{array}$ & 4 & $5 \%$ \\
\hline \multirow{4}{*}{$\begin{array}{l}\text { Internet } \\
\text { connection }\end{array}$} & Home Wifi & 13 & $18 \%$ \\
\hline & Café Wifi & 4 & $5 \%$ \\
\hline & Campus Wifi & 8 & $11 \%$ \\
\hline & $\begin{array}{l}\text { Personal } \\
\text { internet data }\end{array}$ & 66 & $90 \%$ \\
\hline \multirow[t]{3}{*}{ Device } & Laptop & 25 & $34 \%$ \\
\hline & Tablet & 1 & $1 \%$ \\
\hline & Smartphone & 70 & $96 \%$ \\
\hline \multirow{5}{*}{$\begin{array}{l}\text { Length } \\
\text { internet-related } \\
\text { activities (hour) }\end{array}$} & $\begin{array}{l}\text { less than } 1 \\
\text { hour }\end{array}$ & 3 & $4 \%$ \\
\hline & $1-2$ hours & 19 & $26 \%$ \\
\hline & 3-4 hours & 16 & $22 \%$ \\
\hline & 5-6 hours & 13 & $18 \%$ \\
\hline & $\begin{array}{l}\text { More than } 6 \\
\text { hours }\end{array}$ & 22 & $30 \%$ \\
\hline \multirow{4}{*}{$\begin{array}{l}\text { E-learning } \\
\text { experience }\end{array}$} & Never & 47 & $64 \%$ \\
\hline & Rarely & 6 & $8 \%$ \\
\hline & $\begin{array}{l}\text { Once in a } \\
\text { while }\end{array}$ & 18 & $25 \%$ \\
\hline & Often & 2 & $3 \%$ \\
\hline
\end{tabular}

\subsection{The Goodness of fit outer model}

To test the goodness of fit outer model, researchers used the loading factor indicator, cross-loading, composite reliability, and average variance extracted (AVE). Of the 16 indicators tested, the SI1 indicator was deleted because it had an outer loading of less than 0.7 (0.591). After that, the researchers again tested these indicators with the results presented in Table 3 and Table 4.

Table 3. Loading factor, cross loading

\begin{tabular}{|l|c|c|}
\hline Indicators & $\begin{array}{l}\text { Loading factor } \\
>0.7\end{array}$ & $\begin{array}{l}\text { Crossloading }> \\
\text { other indicators } \\
\text { value }\end{array}$ \\
\hline ILE1 & 0.720 & Yes \\
\hline ILE2 & 0.875 & Yes \\
\hline ILE3 & 0.926 & Yes \\
\hline ILE4 & 0.824 & Yes \\
\hline PS1 & 0.930 & Yes \\
\hline PS2 & 0.941 & Yes \\
\hline PS3 & 0.938 & Yes \\
\hline PU1 & 0.871 & Yes \\
\hline PU2 & 0.868 & Yes \\
\hline PU3 & 0.910 & Yes \\
\hline SI2 & 0.918 & Yes \\
\hline SI3 & 0.919 & Yes \\
\hline
\end{tabular}

Table 4. Composite Reability and Average Variance Extracted (AVE)

\begin{tabular}{|c|c|c|}
\hline Variables & $\begin{array}{l}\text { Composite } \\
\text { reability }\end{array}$ & $A \bigvee E>0.5$ \\
\hline Interactive learning & 0.905 & 0.705 \\
\hline Perceived satisfaction & 0.955 & 0.877 \\
\hline Perceived usefulness & 0.914 & 0.780 \\
\hline Social Influence & 0.915 & 0.843 \\
\hline
\end{tabular}

Based on the outer model indicators presented, all loading factors, cross-loading, composite reliability, and AVE have met the specified standards.

\subsection{Goodness of fit inner model}

The inner model Goodness of Fit (GoF) test is performed to see the suitability of the relationship between variables. Several parameters were used in the GoF test, namely $\mathrm{R}$ square, $\mathrm{f}$ square, and $\mathrm{Q}$ square (Table 5).

Table 5. R square, f square, dan $\mathrm{Q}$ square

\begin{tabular}{|l|c|c|}
\hline \multicolumn{3}{|c|}{ R square } \\
\hline Variables & R Square & $\begin{array}{c}\text { R Square } \\
\text { Adjusted }\end{array}$ \\
\hline Perceived satisfaction & 0.682 & 0.673 \\
\hline Perceived usefulness & 0.548 & 0.535 \\
\hline \multicolumn{2}{|c|}{ F square } \\
\hline
\end{tabular}




\begin{tabular}{|c|c|c|c|c|}
\hline Variables & ILE & PS & PU & $\mathrm{SI}$ \\
\hline $\begin{array}{l}\text { Interactive learning } \\
\text { (ILE) }\end{array}$ & & 0.526 & 0.108 & \\
\hline \multicolumn{5}{|l|}{$\begin{array}{l}\text { Perceived satisfaction } \\
\text { (PS) }\end{array}$} \\
\hline $\begin{array}{l}\text { Perceived usefulness } \\
\text { (PU) }\end{array}$ & & 0.302 & & \\
\hline Social Influence (SI) & & & 0.363 & \\
\hline \multicolumn{5}{|c|}{ Q square } \\
\hline Variables & \multicolumn{4}{|c|}{$\mathrm{Q}^{2}(=1-\mathrm{SSE} / \mathrm{SSO})$} \\
\hline \multicolumn{5}{|l|}{$\begin{array}{l}\text { Interactive learning } \\
\text { (ILE) }\end{array}$} \\
\hline $\begin{array}{l}\text { Perceived satisfaction } \\
\text { (PS) }\end{array}$ & \multicolumn{4}{|c|}{0.532} \\
\hline $\begin{array}{l}\text { Perceived usefulness } \\
\text { (PU) }\end{array}$ & \multicolumn{4}{|c|}{0.393} \\
\hline Social Influence (SI) & & & & \\
\hline
\end{tabular}

The Adjusted R square measures how far the model can explain endogenous variation. Based on data processing, the adjusted $\mathrm{R}$ square for variable perceived satisfaction is 0.673 , which is considered substantial. Meanwhile, for the variable perceived usefulness, the $\mathrm{R}$ square has a value of 0.535 , which is moderate, approaching substantial. The size of F square shows the estimated path relationships in the structural model. The $\mathrm{F}$ square of interactive learning value toward perceived satisfaction, social influence towards perceived usefulness, and perceived usefulness towards perceived satisfaction is categorized as a strong influence with values of $0.526,0.363,0.302$, respectively. Meanwhile, the value of $\mathrm{F}$ square interactive learning for perceived usefulness is 0.108 , which is moderate. The value of $\mathrm{Q}$ square $>0$ indicates evidence that the observed values have been appropriately reconstructed so that the model has predictive relevance. The $\mathrm{Q}$ square value of perceived satisfaction and perceived usefulness (0.532 and 0.393) shows a value greater than 0 , which means that the variable has predictive relevance.

\subsection{Structural Equation Modeling}

To test the relationship between variables, researchers used partial least squares structural equation modeling (PLS-SEM). PLS-SEM is useful for analyzing the relationship between small sample size variables and a complex model and does not require database assumptions [19]. The indicators used to examine the relationship between variables are tstatistic (Figure 4), p-value, and original sample (o). The results of the three statistical values can be seen in Table 6.

Table 6. t-statistic, p-value, dan original sample

\begin{tabular}{|l|r|r|l|}
\hline Variables & $\begin{array}{l}\text { Original } \\
\text { Sample } \\
\text { (O) }\end{array}$ & $\begin{array}{l}\text { T } \\
\text { Statistics }\end{array}$ & $\begin{array}{l}\text { Palues } \\
\text { Value }\end{array}$ \\
\hline $\begin{array}{l}\text { Interactive } \\
\text { learning -> } \\
\text { Perceived } \\
\text { satisfaction (H1) }\end{array}$ & 0.521 & 3.567 & 0.000 \\
\hline $\begin{array}{l}\text { Interactive } \\
\text { learning -> } \\
\text { Perceived } \\
\text { usefulness (H2) }\end{array}$ & 0.286 & 1.924 & 0.055 \\
\hline $\begin{array}{l}\text { Social Influence- } \\
>\text { Perceived } \\
\text { usefulness (H3) }\end{array}$ & 0.525 & 4.320 & 0.000 \\
\hline $\begin{array}{l}\text { Perceived } \\
\text { usefulness -> } \\
\text { Perceived } \\
\text { satisfaction (H4) }\end{array}$ & 0.395 & 3.638 & 0.000 \\
\hline
\end{tabular}




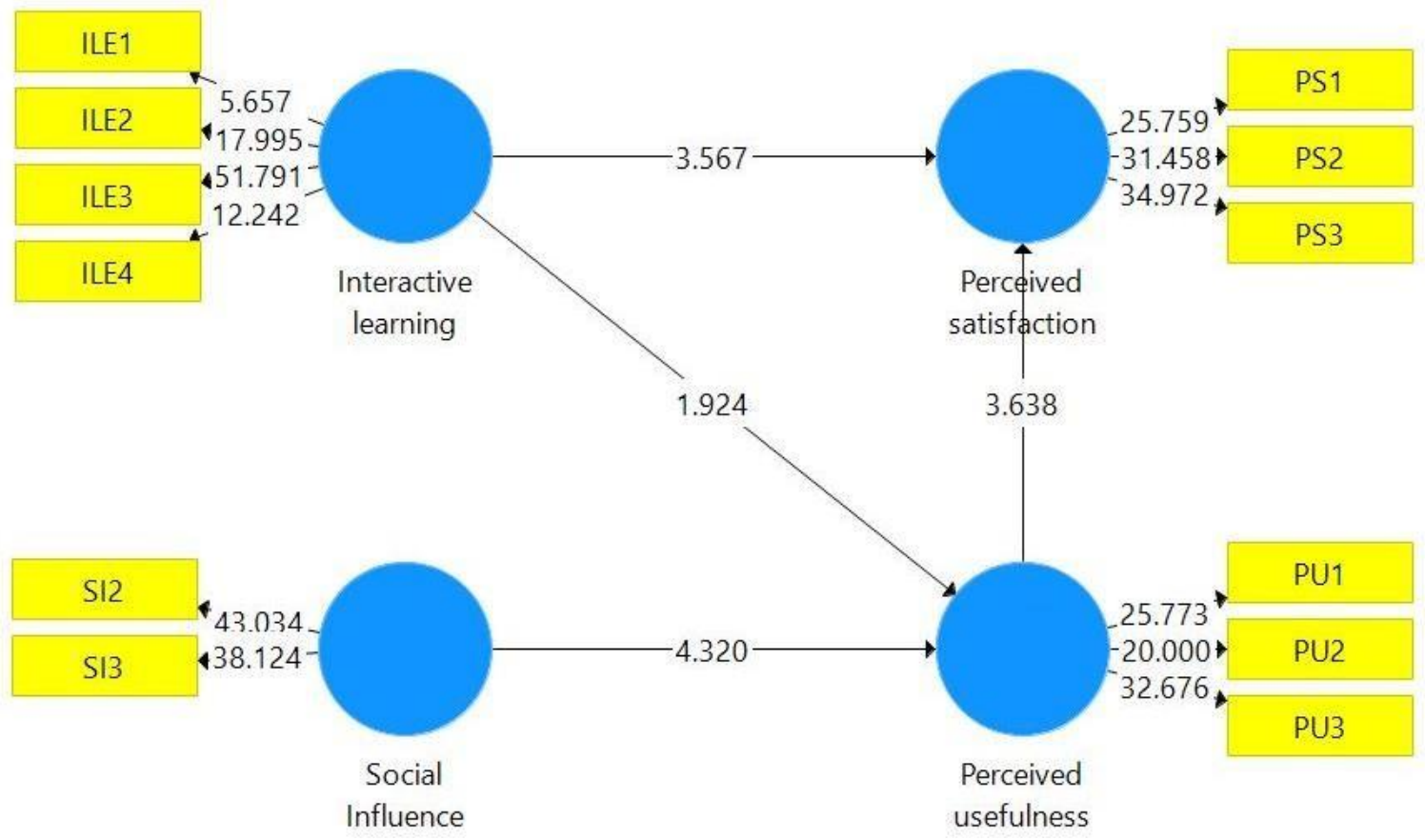

Figure 2 t-statistic values

Based on the SEM test, three of the four proposed hypotheses are accepted (H1, H3, H4), and only $\mathrm{H} 4$ is rejected.

Interactive learning has a significant positive relationship with perceived satisfaction $(\gamma=0.521, \mathrm{t}=$ 3.567); therefore $\mathrm{H} 1$ is accepted. These results are consistent Liaw \& Huang, and Sharma et al., with [9], [12] and Liaw and Huang [10]. These findings confirm that the implementation of interactive e-learning can increase the satisfaction of e-learning users.

Statistical data on interactive learning for perceived usefulness was insignificant $(\gamma=0.286, \mathrm{t}=1.924)$. Therefore, $\mathrm{H} 2$ is rejected. This result contradicts the findings of Liaw [13]. This difference in results could be due to differences in the e-learning platforms used by respondents. This study uses the Moodle platform, where the system provides standard features with less user change options.

Furthermore, social influence has a significant positive effect on perceived usefulness $(\gamma=0.525, \mathrm{t}=$ 4,320); therefore, H3 is accepted. These results support the research model developed by Liaw [13]. They indicate that creating a positive environment for $\mathrm{e}$ learning students is very important to increase user satisfaction with e-learning.

Finally, the variable perceived usefulness has a significant positive effect on perceived satisfaction $(\gamma=$ $0.395, \mathrm{t}=3.638)$, which means that $\mathrm{H} 4$ is accepted.
These results align with the model compiled by Liaw [13]. The higher the benefits felt by users, the higher the satisfaction with e-learning.

\section{CONCLUSION}

Based on the results of this study, several conclusions can be drawn and their implications for instructors who conduct online learning and those in charge of information technology. First, interactive learning needs to be developed in online learning because it affects student satisfaction. The implementation of interactive learning can be applied as creating interesting modules, quizzes in the form of games, and tutor activeness in building a classroom atmosphere. Second, peer influence needs to be controlled. The positive peer influence will increase the sense of usefulness towards e-learning, and vice versa. Building a mutually supportive environment in the e-learning process can be formed by providing counseling at the beginning of lectures. Finally, the benefits of e-learning need to be addressed because it also affects satisfaction. The benefits of e-learning compared to face-to-face learning, such as freedom in determining the lessons to be studied and being more independent, must be felt by students.

\section{ACKNOWLEDGMENT}

This research was funded by the PPBL LP3M 2020 grant Universitas Andalas. 


\section{REFERENCES}

[1] R. T. Raab, W. W. Ellis, and B. R. Abdon, "Multisectoral partnerships in e-learning A potential force for improved human capital development in the Asia Pacific," vol. 4, pp. 217 229, 2002.

[2] D. Y. Shee and Y.-S. Wang, "Multi-criteria evaluation of the web-based e-learning system: A methodology based on learner satisfaction and its applications," Comput. Educ., vol. 50, pp. 894 905, 2008.

[3] P.-C. Sun, R. J. Tsai, G. Finger, Y.-Y. Chen, and D. Yeh, "What drives a successful e-Learning? An empirical investigation of the critical factors influencing learner satisfaction," Comput. Educ., vol. 50, no. 4, pp. 1183-1202, May 2008.

[4] D. Bouhnik and T. Marcus, "Interaction in distance- learning courses," J. Am. Soc. Inf. Sci. Technol., vol. 57, no. 3, pp. 299-305, 2006.

[5] K. J. Kim and C. J. Bonk, "The future of online teaching and learning in higher education: the survey says," Educ. Q., vol. 29, pp. 22-30, 2006.

[6] J. Dutton and J. Perry, "How do online students differ from lecture students?," J. Manag. Inf. Syst., vol. 18, no. 4, pp. 169-190, 2002.

[7] K. Swan, "Virtual interaction: Design factors affecting student satisfaction and perceived learning in asynchronous online courses,' Distance Educ., vol. 22, no. 2, pp. 306-331, 2001.

[8] L. F. Motiwalla, "Mobile learning: A framework and evaluation," Comput. Educ., vol. 49, no. 3, pp. 581-596, 2007.

[9] S. Liaw and H. Huang, "Developing a Collaborative e-Learning System Based on Users ' Perceptions," pp. 751-752, 2007.

[10] S. S. Liaw and H. M. Huang, "Perceived satisfaction, perceived usefulness and interactive learning environments as predictors to selfregulation in e-learning environments," Comput. Educ., vol. 60, no. 1, pp. 14-24, 2013.

[11] S. S. Liaw, "Considerations for developing constructivist Web-based learning," Int. J. Instr. Media, vol. 31, no. 3, pp. 309-321, 2004.

[12] S. Sharma, G. Dick, W. Chin, and L. Land, "Self- Regulation and E-Learning," in European Conference on Information Systems (ECIS), 2007, pp. 383-394.

[13] S. S. Liaw, "Investigating students' perceived satisfaction, behavioral intention, and effectiveness of e-learning: A case study of the Blackboard system," Comput. Educ., vol. 51, no. 2, pp. 864-873, 2008.

[14] V. Venkatesh, M. G. Morris, G. B. Davis, and F. D. Davis, "User acceptance of information technology: Toward a unified view," $M I S Q$. Manag. Inf. Syst., vol. 27, no. 3, pp. 425-478, 2003.

[15] P. W. C. Prasad, A. Maag, M. Redestowicz, and L. S. Hoe, "Unfamiliar technology: Reaction of international students to blended learning," Comput. Educ., vol. 122, pp. 92-103, 2018.

[16] M. Virvou and G. Katsionis, "On the usability and likeability of virtual reality games for education: the case of VR-ENGAGE," Comput. Educ., vol. 50, pp. 154-178, 2008.

[17] R. Kneebone, "Simulation in surgical training: educational issues and practical implications," Med. Educ., vol. 37, no. 3, pp. 267-277, 2003.

[18] W. J. Doll and G. Torkzadeh, "The measurement of end-user computing satisfaction," MIS $Q$., vol. 12, no. 2, pp. 259-274, 1988.

[19] C. Cassel, P. Hackl, and A. H. Westlund, "Robustness of partial least-squares method for estimating latent variable quality structures," $J$. Appl. Stat., vol. 26, no. 4, pp. 435-446, 1999. 